\title{
A Magneto-electric Phenomenon
}

This content has been downloaded from IOPscience. Please scroll down to see the full text. 1884 Proc. Phys. Soc. London 6218

(http://iopscience.iop.org/1478-7814/6/1/320)

View the table of contents for this issue, or go to the journal homepage for more

Download details:

IP Address: 128.6.218.72

This content was downloaded on 02/10/2015 at 05:54

Please note that terms and conditions apply. 
XIX. A Magneto-electric Phenomenon. By C. V. BoYs, A.R.S.M., Demonstrator of Physics at the Science Schools, South Kensington*.

Every one is familiar with the effect produced when a colper disk is set to spin in a powerful magnetic field : the currents induced by the motion of the disk act in such a direction as to oppose the motion, which thercfore spcedily ceases. Faraday observed that if, instead of being set to spin, a disk is merely suspended between the poles of an electrismagnet, it will in general be disturbed whenever the current in the coils of the electromagnet is made or broken. If it lie with its plane parallel or at right angles to the lines of force, no disturbunce will be alparent if the lines of force where they are included by the disk are parallel. But if the plane of thic disk makes an angle $\alpha$ with the parallel lines of force, then on mak ingthe current in the electromagnet an impulse is given tending to diminish the angle $\alpha$, while breaking the current gives an impulse tending to increase the angle $\alpha$.

A gain, if the angle $\alpha$ be $90^{\circ}$, so as to eliminate this twisting effect, no movement will be visible at the making or the breaking in a parallel field ; but if the disk be placed in a field with diverging lines of force, in which, of course, the strength diminishes as the lines separate, and if it be placed symmetrically so as to include the greatest number (i.e. with it: plane at right angles to those lines passing through its centre), then, on making the current, it will receive an impulse causing it to more parallel to itself along the lines of force towards the weaker part of the field, and at the breaking it will receive an impulse more evident in the opposite direction. If this radiating field is produced between a pointed and a flat pole, the disk will, on making the current, appear to be repelled from, and, on breaking, to be attracted by, the pointed pole. So powerful is this effect that a piece of impure copper, which is strongly magnetic, is repelled from the pointed pole on making, and attracted on breaking, the current, thus appearing at first sight strongly diamagnetic.

Though these impulses must have been observed by most 
experimentalists, their amount has not been, so far as I am aware, determined in absolute units, nor have they been turned to account for making any measurements. As they seem to aftord one of the most convenient methods of drtermining conductivity and field-intensity, perhaps a short farer on the sulject, even though it be incomplete, may be of interest to this Society.

The explanation of the motions described will he olvious, but it may be well to give it at length for the sake of arriving at quantitative results. In the first place, let the lines of furce be parallel, so that the field is of uniform strength. Let a ring of (small) section s, of specific resistance $\rho$, and of radius $r$, be placed in the field, with its plane making an angle $\alpha$ with the lines of foree. Iet the strength of the field be H wnits. Then during a small increment of field-intensity dli, in the time $d t$, a current will be induced in the ring of the strength

$$
\frac{r s \sin \alpha}{2 \rho} d t \mathrm{H} \text {. }
$$

This current in the field $\mathrm{H}$ will produce a twisting tendency to increase $\alpha$ with a diminishing, or to diminish $\alpha$ with an increasing field, represented by the couplo

$$
-\frac{\pi r^{3} s \mathrm{H} \sin 2 \alpha}{4 \rho} d \mathrm{II}
$$

From this it is clear that the couple varies inversely as the time $d t$ occupied in making any small change of field-intencity dII, but it lasts for the time $d t$; therefore the momentum acquired by the suspended disk, if free to move, will be indefendent of the rate at which any small change in the magnetic ficld maly be made, but will depend only on its amount, providrod that the time is not sufficient for the angle a to have perceptibly altered during the change. Since this is true of any element, it is true of all; so the momentum acquired by the ring is a direct measure of any total change in the strengrth of the field in which it lies, no matter by what law it changes in strength. If at the end of any rapid change the field remains of any strength, the motion of the ring will be rinpiilly stopped by the well-known damping action, of which I shill have more to say later. If, however, the field sinks to zoro, 
or nearly so, the momentum acquired can be measured and the original intensity determined.

The current induced in the ring will of course react on th. field and bend the lines of force in such a manner as to hindir their passing through its elge, that is to delay the ching w included fiell-intensity; but the impulse is independent of the time or the manner in which the field changes, so it cam. not be rffected to any extent by this cause.

Since the impulse given to the disk during any element of time is

$$
-\frac{\pi r^{3} s \mathrm{H} \sin 2 \alpha}{4 \rho} \frac{d \mathrm{H}}{d t}
$$

lle total impulse while $H$ changes between 0 and $H$ will b.

$$
-\frac{\pi r^{3} s \mathrm{H}^{2} \sin 2 \alpha}{8 \rho} \text {. }
$$

If the moment of inertia of the disk be $\mathbf{M}$, and the torsional value of the supporting wire be $\mathrm{T}$, the angular relocity $\omega$ generated will be

$$
\omega=-\frac{\pi r^{3} s \mathrm{H}^{2} \sin 2 \alpha}{\gamma \rho M}
$$

and the throw of the ring $\theta$ will be

$$
\theta=-\frac{\pi r^{3} 8 \mathrm{H}^{2} \sin 2 \alpha}{8 \rho \sqrt{\mathrm{MT}}}
$$

The action on a disk may be considered as the sum of the actions on the several elementary rings of which it is composed, for there cannot be any tendency for any part of the currents to cross over the elementary circles. The impulse therefore on a disk of radius $r$ and thickness $s$ will be

$$
-\frac{\pi r^{4} s \mathrm{H}^{2} \sin 2 \alpha}{32 \rho}
$$

and the impulse on a disk of radius $r_{2}$ with a concentric hole of ralius $r_{1}$ will be

$$
-\frac{\pi s H^{2} \sin 2 \alpha}{32 \rho}\left(r_{2}^{4}-r_{1}^{4}\right)
$$


Since the moment of inertia of a disk is also proportional to the fourth power and to the thickness, so long as the thickness is small, it will appear that the velocity imparted to a disk of any size or thickness, or to a ring, during a change in a magmite field will be the same. To what extent a correction should be applied to these results for solf-induction between different parts of the disk I am not prepared to say; their alculation would give trouble.

For comparing one ficld with another, disks or rings of metal may bo used; but for abolute meanemenents, as it would be impossible to masure the exact comluctivity of a lisk, a coil is preferable. By employing disks of different metals their conductivities can be compared without the troulle of drawing into wire or cutting into long strips.

It will be found that a coil of area $A$ and resistance $R$ will, under a torsion $\mathrm{T}$, experience a throw

$$
\theta=-\frac{\Lambda^{2} \mathrm{I}^{2} \sin 2 \alpha}{4 \mathrm{~L} V \mathrm{M} \mathrm{T}^{-}}
$$

If, instead of a disk, a sphere be ned, no twisting shonlul ho experienced if the conductivity in different directions is the same. If, howerer, there is a phame of grratest or least conductivity, it should he possible to discover it. Crystallization (1) inechanical truatment might give rise to such phanes in

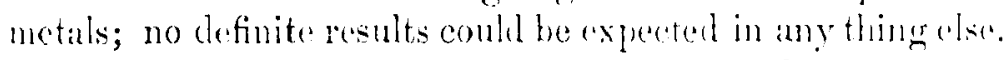

I have refored to the apparent repulsion and attraction of a disk of metal by a pointert pole at the making and loreaking of the magnetiaing current. As the lines from such a pole raliate ontwards, they are not nomal to the metal cxeppt in fhe misldle. On their passigge inwierts or ontwats they grive lise to circular currents temling to move each part of the disk nomally to the lines of force. There is therefore a longitudinal component away from the point of radiation during an increase in the field, and towarls it during a diminution of the field. A closed coil of wire is sulject to the same forces. If a coil be male of uncovered conpere wire in the form of a donble helix with the ends joined toggether, and if the conrolutions are separate so as nowhere to touch one another, thre growth of the nagnetic ficld can be watched hy placing the coil nearly 
over one pole. On making the current the field begins to grow, at first quickly and afterwards more slowly. The coil will receive a push and will extend itself. As the push diminishes in amount, owing to the diminishing rate of growth of the magnetic field, the coil will gradually regain its former shape. It might be thought that the slow recoil is simply duo to the damping action of the field; but this is not sufficient to account for it, as when the field is fully grown the coil will, on being forcibly drawn out, recover its shape much more quickly. On breaking the magnetizing current, the impulse in the opposite direction, being the same as before but lasting for so much shorter a time, is far more evident.

My first experiments were made with a view to determin? whether the impolse was proportional to $\sin 2 \alpha$ when other things remained the samo. I therefore cemented a disk of metal (a half-crown) to an ebonite rod carrying a glass index and hung by a torsion-wire of platinum. The glass index travelled over a card divided into degrees; and the wire to which the upper end of the torsion-wire was soldered also carried a pointer, the position of which could, if desired, be read on a divided card. The disk was suspended between two parallel polar faces of iron. The upper index was turned until, on making and hreaking the current, the lower index showed no sign of motion. It could thus be placed within a small fraction of a degree, so that a was either $90^{\circ}$ or $0^{\circ}$. The lower card was then adjusted, and the uper index turned so that the lower rested successively at $5^{\circ}, 10^{\circ}, 15^{\circ}$, \&c. up to $90^{\circ}$. The negative impulse on making, and the positive impulse on breaking, the current were observed by the throw of the lower index. These are given in the second and third columns of the following Table. In the fourth column is a series of numbers in the proportion of $\sin 2 \alpha$, the largest number being male to agree with the observed positive throw. The close agreement of the other numbers shows clcarly that, on breaking the circuit, the impulse is truly proportional to $\sin 2 \alpha$. Examination shows that the negative impulses, though in reality equal to the others, are apparently much less in amount, that they are not even in proportion, and not only this, but that the corresponding values on either side of $45^{\circ}$ are 
TABle I.

\begin{tabular}{|c|c|c|c|}
\hline $\begin{array}{c}\text { Position of } \\
\text { rest. }\end{array}$ & $\begin{array}{c}\text { Negative } \\
\text { throw. }\end{array}$ & $\begin{array}{c}\text { Positive } \\
\text { throw. }\end{array}$ & $\begin{array}{c}\text { Caleulated } \\
\text { positive } \\
\text { throw. }\end{array}$ \\
\cline { 1 - 2 } 5 & 1 & $-1 \cdot 5$ & $4 \cdot 6$ \\
10 & 2 & 9 & $9 \cdot 1$ \\
15 & 3 & 13 & $13 \cdot 2$ \\
20 & $4 \cdot 5$ & 17 & $17 \cdot 1$ \\
25 & 5 & 20 & $20 \cdot 3$ \\
30 & 6 & $22 \cdot 5$ & 23 \\
35 & 7 & $24 \cdot 5$ & 25 \\
40 & $7 \cdot 8$ & $26 \cdot 2$ & $26 \cdot 2$ \\
45 & $8 \cdot 8$ & $26 \cdot 5$ & $26 \cdot 5$ \\
50 & $8 \cdot 5$ & $26 \cdot 3$ & $26 \cdot 2$ \\
55 & $8 \cdot 2$ & $24 \cdot 5$ & 25 \\
60 & $7 \cdot 3$ & 22 & 23 \\
65 & $7 \cdot 5$ & 20 & $20 \cdot 3$ \\
70 & $6 \cdot 5$ & 16 & $17 \cdot 1$ \\
75 & $5 \cdot 5$ & $12 \cdot 5$ & $13 \cdot 2$ \\
80 & $3 \cdot 5$ & 9 & $9 \cdot 1$ \\
85 & 2 & 4 & $4 \cdot 6$ \\
\hline
\end{tabular}

not the same. This want of symmetry is clearly shown by fig. 1. The discrepancy is due to the fact that the disk is brought to rest by the damping action of the field as well as by the torsion of the wire, and that the damping action is grenter as the angle is less, being : : $\cos ^{2} \alpha$.

Fig. 1.

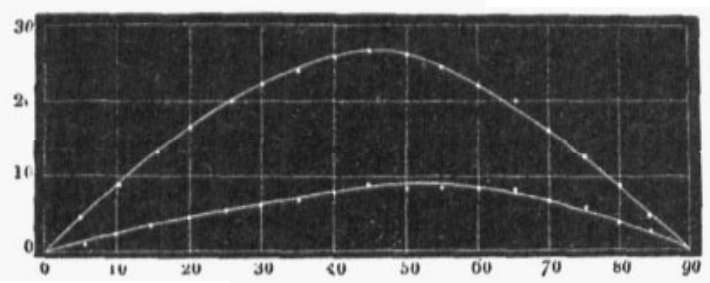

I thought it would be interesting to determine to what angle the disk would be thrown if the torsion of the wire did not act. I therefore suspended, instead of the disk, the coil used in the absolute experiments by a silk thread, adjusted the lower card by the method of no throw, and brought the index to rest successively over $10^{\circ}, 20^{\circ}, 30^{\circ}$, \&c. up to $90^{\circ}$. The index came to rest at the series of positions shown in column 2 of the following Table:- 
TABLE II.

\begin{tabular}{|c|c|}
\hline \multicolumn{2}{|c|}{ Pointer fell } \\
\hline From & To \\
\hline 10 & $3 \cdot 6$ \\
20 & 6 \\
30 & 10 \\
40 & 13 \\
45 & 16 \\
50 & 18 \\
60 & 22 \\
70 & 29 \\
80 & 39 \\
\hline
\end{tabular}

The same results are shown graphically in fig. 2 . It is interesting to note that the curve shown is a natural curve depending on circular functions only. It is independent of the nature of material, snch as condnctivity, moment of inertia, or of the strength to which the field is made to grow from

Fig. 2.

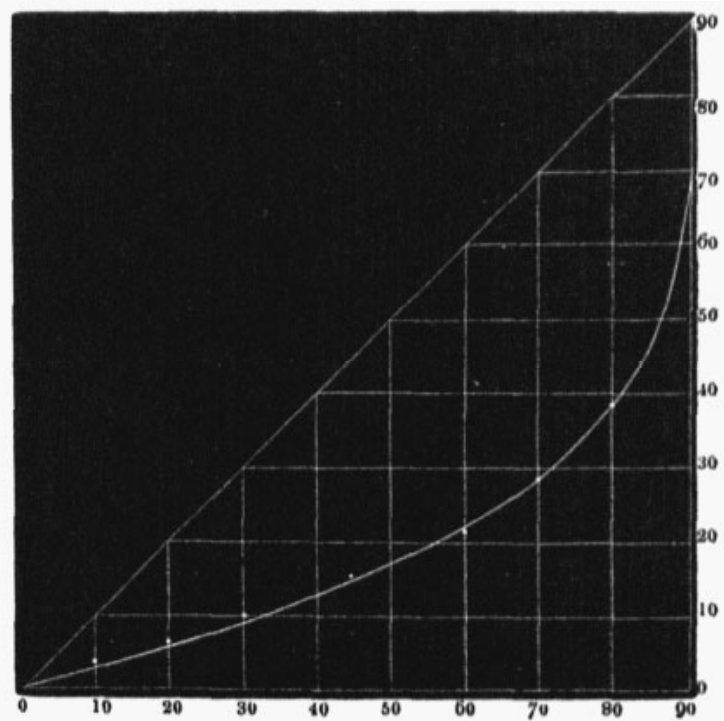


r. It is subject to a small error, for I did not destroy the moihlat magnetism. That the effect of this is appreciable is wilme for in one seriess of "xperiments with a disk the throw wh making was always from $45^{\circ}$ to $333^{\circ}$; but the first time that the direction of the magnetizing current was changed ith throw was from $45^{\circ}$ to $35^{\circ}$, altere which it was from $45^{\circ}$ to $: \because{ }^{\prime}$, as before. This diminution at the first reversal was always the sume. I found almost the sane fall with the halli-erown :n with the coil, and with one coll as with ten cells. There were slight differences, but not more than draughts from which 1 did not shield the neadle would have areounterl for. The lower angle can be read with precision, but the higher angles become difficult to observo as the damping influence diminishes. The position $\alpha=90^{2}$ is one of instalility ; for howwer slight a velocity is given to the disk, it will mot be bought th rest for a consilerable time, owing to the very minute nature

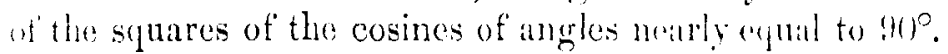

The last series of experiments was made with a viow to determine whether the strength of fied determined hy ohsorration of the throw of the disk at breaking acreed with the strength determined by some recognizid mothod. I therefore mate a small coil of twelvo turns of eppere wire of $1 \cdot 15$ centim. radius and with a resistance of $(0 \cdot 1) 5$ ohm. The area of the coil was 79.4 square centim. The moment of incrtia of coil and index was found by compariom with a "ylinder to be 58.1 units, and the torsional value of the supforting wire to be 17,000 units. The plane of the coil was arjusted by the usual method to zero, and then set to $45^{\circ}$. The currents from $10,9,8$, \&c. to 1 Grove cells were sent in succession through the coils of the electromagnet and throngh a siemens electrodynamometer. The following lable shows the amounts of the positive and negative impulses, the st rengths of the magnetizing currents in amperes, and the field-intensities calculated from the positive throws by the formula

$\mathrm{H}^{2}=9311000 \times$ Throw neasured in degrees. 
TABLE III.

\begin{tabular}{|c|c|c|c|c|}
\hline $\begin{array}{l}\text { Number of } \\
\text { cells. }\end{array}$ & $\begin{array}{l}\text { Magnetizing } \\
\text { current, } \mathrm{i}_{i} \text { ' } \\
\text { amperis. }\end{array}$ & $\begin{array}{l}\text { Negrativo } \\
\text { throw. }\end{array}$ & $\begin{array}{l}\text { Positire } \\
\text { throw. }\end{array}$ & $\begin{array}{l}\text { Calculaterl } \\
\text { field, in ah. } \\
\text { solute units. }\end{array}$ \\
\hline 10 & 11.85 & $10 \%$ & $27 \cdot 5$ & 16,000 \\
\hline 9 & $11 \cdot 2$ & 9 & 26 & 15,600 \\
\hline 8 & $10 \div 4$ & $8 \cdot 2$ & 245 & 15,100 \\
\hline 7 & $3 \cdot 47$ & 7 & 225 & 14,500 \\
\hline 6 & $8 \cdot 63$ & 6 & 213 & 14,100 \\
\hline 5 & $7 \cdot 60$ & $4 \cdot 8$ & 192 & $13,4(k)$ \\
\hline 4 & $6 \cdot 63$ & $3 \cdot 3$ & 16.5 & 12,400 \\
\hline 3 & $5 \cdot 18$ & $2 \cdot 2$ & 13 & $11,0 \times 00$ \\
\hline 2 & $3 \cdot 67$ & 1 & 8 & 8,630 \\
\hline 1 & 1.83 & 0.2 & 28 & 5,070 \\
\hline
\end{tabular}

The ends of the coil which were soldered together were the'n unsoldered without disturbing the soldered connexion betwe"ll the torsion-wire and one end. The other end was bent so as to dip into a small mercury-cup in the axial line, so that a known current, measured by a second electrodynamometer, could be sent through the coil. During this chinge no part of the apparatus was moved at all ; it was, however, necessary to redetermine the zero position, which was now rather more difficult, for the resistance of the torsion-wire was so great in comparison with that of the coil alone, that the throw at any angle was only about one tentl of what it was before. As hefore, the current from 10 to 1 cells was sent successively through the coils of tho electromagnet and an electrodynamometer. The current from a Daniell cell was sent through tho suspended coil and measured. In the fourth column of the following Table will be found the deflection of the coil due to currents tabulated in columns 2 and 3 . In the fiftl colunn is the defection due to the residual magnetism; and in the sixth column the strength of field in absolute units, calculated from the formula

$$
\mathrm{H}=\frac{3 \cdot 73 \times \text { leflection in degrees }}{\text { deflecting current in absolute units } \times \cos \delta} \text {. }
$$


Table IV.

\begin{tabular}{|c|c|c|c|c|c|}
\hline $\begin{array}{c}\text { Number of } \\
\text { cells. }\end{array}$ & $\begin{array}{l}\text { Magnetizing } \\
\text { current, in } \\
\text { amperes. }\end{array}$ & $\begin{array}{l}\text { Deflecting } \\
\text { current, in } \\
\text { amperes. }\end{array}$ & $\begin{array}{l}\text { Deflection } \\
\quad=\delta\end{array}$ & $\begin{array}{c}\text { Deflection } \\
\text { due to } \\
\text { residual } \\
\text { magnetism. }\end{array}$ & $\begin{array}{c}\text { Calculated } \\
\text { field, in } \\
\text { absolute } \\
\text { units. }\end{array}$ \\
\hline 10 & 11.92 & 514 & 65 & 4 & 11,200 \\
\hline 9 & 1105 & $530^{*}$ & 64 & 4 & 10,260 \\
\hline 8 & $10 \div 2$ & 502 & 63 & 4 & 10,320 \\
\hline 7 & $9 \cdot 48$ & $\cdot 496$ & $62 \cdot 5$ & 4 & 10,150 \\
\hline 6 & $8 \cdot 63$ & $\cdot 480$ & $61 \cdot 5$ & 4 & 10,050 \\
\hline 5 & $7 \cdot 60$ & 480 & $60 \cdot 3$ & 4 & 9,470 \\
\hline 4 & $6 \cdot 45$ & 480 & 59 & 4 & 8,930 \\
\hline 3 & $5 \cdot 14$ & $\cdot 480$ & 57 & 4 & 8,120 \\
\hline 2 & $3 \cdot 67$ & 480 & $51 \cdot 5$ & 4 & 6,470 \\
\hline 1 & 1.98 & $\cdot 480$ & 40.5 & $4 \cdot 5$ & 4,140 \\
\hline
\end{tabular}

* Obviously over-estimated, hence small results.

The resilual magnetism was always the same till one cell only had been employed to excite the electromagnet, when the deflection was clearly greater. This I repeated several times with one and with more than one cell : a deflection of $4 \frac{1}{2}^{\circ}$ was always obtained from one cell, and of $4^{\circ}$ from more than one cell. To obtain a still higher residual magnetic effect, I drew the terminal along a fine wire and gradually diminished the field; by this menns I obtained a residnal field giving a deflection of $5^{\circ} \cdot 4$. The magnetic fields corresponding to the deflections $4,4 \frac{1}{2}$, and 5.4 are 312,352 , and 422 absolute units.

Fig. 3 shows the field-intensity measured by the two Fì. 8.

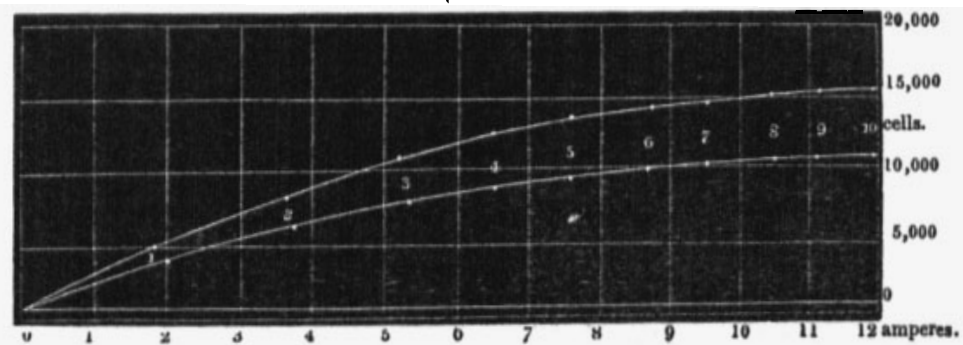


methods. They do not agree, nor are they quite proportional, nevertheless they are of the same order of magnitude. Th. discrepancy is greater than would be expected from errors of an experimental kind, even thongh the apparatus was hastily improvised. Nevertheless the agreenent, such as it is, show, that it will he worth while to carry out a series of experiments with the accuracy and care that are needed in physical invetigations. This I intend to do as soon as I am able. It will then perhays be possible to tell whether this method al' determining conductivity or field-intensity is to be rolical upon: it certainly in convenience and simplicity complates very favourably with any of the usual methods.

XX. Experiments on the Velocity of Sound in atir.

$$
\text { By D. J. BLAikLeY*. }
$$

[Plate XII.]

I HAVE to bring before you this afternoon the results of a fow experiments carried out in continuation of the serius brought to your notice last November. Before considering the relocities obtained, however, it may be well to show liy experiment the rason for the doubt in my mind as to the: absolute reliability to be placed upon records obtained from membrances as used by Regnault and Le Ronx; and also to explain a little more fully my reason for discarding the use: of organ-pipes, speaking under a considerable pressure and with good musical tone, as used by Dulong.

If we take a short tube, say 5 inches long, with a short inner sliding-piece for arjustment of length, and close one end with a diaphragm of gold-beater's skin, against which a beal hung by silk falls, we have a very sensitive resonator for the pitch of about $512 \mathrm{v}$. If this tube were closed by a rigrid material instead of by the skin, its length to give the maximum resonance to the $512 \mathrm{v}$. fork would be about $6 \frac{1}{4}$ inches; but on drawing the slide to make the tube of this length there

* Read June 14, 1884, in continuation of paper read November 10 , 1883 (Proc. Physical Society, vol. v. p. 319). 